\title{
Thermal comfort, thermal sensation and skin temperature measurements using demand-controlled ventilation for individual cooling
}

\author{
Håkon Solberg ${ }^{1 *}$, Kari Thunshelle ${ }^{1}$, and Peter Schild ${ }^{1,2}$ \\ ${ }^{1}$ SINTEF Community, Børrestuveien 3, 0373 Oslo, Norway \\ ${ }^{2}$ Oslo Metropolitan University, P.O. Box 4 St. Olavs plass, 0130, Norway
}

\begin{abstract}
An increasing part of modern building's energy demand is due to cooling. An ongoing research project investigates the possibility to reduce the energy consumption from cooling by utilizing an individually controlled active ventilation diffuser mounted in the ceiling. This study looks at thermal sensation and thermal comfort for 21 test persons exposed to an innovative user controlled active ventilation valve, in a steady and thermally uniform climate chamber. Furthermore, the relationship between biometric data from the test persons skin temperature and sweat, and the test persons thermal sensation scores has been investigated. Each test person was exposed to three different room temperatures in the climate chamber, $24^{\circ} \mathrm{C}, 26^{\circ} \mathrm{C}$ and $28^{\circ} \mathrm{C}$ respectively, to simulate typical hot summer conditions in an office in Norway. At a room temperature of $26^{\circ} \mathrm{C}$ it was possible to achieve acceptable thermal comfort for most test persons with this solution, but higher air velocity than $0.75 \mathrm{~m} / \mathrm{s}$ around the test persons bodies at room temperatures of $28^{\circ} \mathrm{C}$ is required to ensure satisfactory thermal comfort.
\end{abstract}

\section{Introduction}

Modern non-residential buildings in Norway are well isolated and have an increasing amount of technical equipment installed which generate heat. Therefore, an increasing energy demand for comfort cooling in such buildings has been observed [1]. This demand is usually met by lowering the supply air temperature from the ventilation systems, sometimes in addition to other cooling systems. New solutions for reducing energy use for comfort cooling is therefore of increasing interest.

The research project ForKlima [2], have documented acceptance for ventilation-based heating with active supply air diffusers. Demand controlled ventilation systems with this kind of technology allows for further development of ventilation-based cooling by increased air velocity using ceiling mounted individually controlled supply air diffusers.

Laboratory experiments were conducted in a climate chamber with test persons over a three weeks period in March 2018. This paper presents the part of measured skin temperature and sweat from palms resulting from the thermal conditions. Also preferred air jet velocities were studied, as well as Eureqa [3] analyses of corresponding thermal sensation and thermal comfort evaluation.

\section{Method}

\subsection{Climate chamber}

The climate chamber used for the experiment was set up to be approximately a standard desk group for four workers in an open office space. Its dimensions were 6.0 $\mathrm{m} * 4.8 \mathrm{~m} * 2.7 \mathrm{~m}$, corresponding to $28.8 \mathrm{~m}^{2}$ floor area. Supply air temperature $\left(21.9 \pm 0.5^{\circ} \mathrm{C}\right)$ and relative humidity $(39.8 \pm 0.5 \%)$ were kept constant throughout the three weeks of experiments. Room air temperature in the climate chamber was changed from week to week. The first week of experiments the air temperature was kept at $24.0 \pm 0.1{ }^{\circ} \mathrm{C}$, the second week at $26.0 \pm 0.2^{\circ} \mathrm{C}$ and the third week of experiments at $27.9 \pm 0.1^{\circ} \mathrm{C}$. A constant, balanced ventilation strategy of $240 \mathrm{~m}^{3} / \mathrm{h}$ was applied to ensure satisfactory air quality for the four test persons in the climate chamber throughout the day. Two standard supply air diffusers and one extract air diffuser were installed in the ceiling. In addition, four specially designed diffusers were installed in the ceiling, one for each participating test person. The air flow in the diffuser was controlled by the experiment leader.

Further details on the climate chamber can be seen in [4].

\footnotetext{
* Corresponding author: hakon.solberg@ sintef.no
} 


\subsection{Experimental design}

A total of 21 test persons with varying age and gender were recruited for the experiment. Of those, 13 were males and eight were females, aged between 20 and 70 . To represent normal working conditions during a hot summer day, the test persons were instructed to wear a pair of jeans, short sleeved shirt and light shoes, with a calculated clo $=0.7$ according to NS-EN ISO 7730 . During a day of experiments, the test persons did light work with a laptop at their designated desk, with an estimated activity level during the experiments of 1.0 to 1.2 met according to NS-EN ISO 7730. 16 of 21 test persons participated all three respective days over the three weeks with different room air temperature in the climate chamber. The remaining five test persons participated two of the three days with different room temperatures.

The test persons were asked to rate the thermal sensation and thermal comfort for the whole body, as well as for different body parts three times each session by electronic questionnaires. A total of nine sessions each day were conducted. Each session lasted 25 minutes with a jet air velocity of Low $(0.25 \mathrm{~m} / \mathrm{s})$ High $(0.5 \mathrm{~m} / \mathrm{s})$ or Extra high $(0.75 \mathrm{~m} / \mathrm{s})$ in front of the body controlled by air flow at their personal diffuser. The thermal sensation scale used was a 9-point scale ( -4 to +4 , an extended 7-point scale, as described in EN ISO 7730). Thermal comfort was rated on a continual scale from very uncomfortable to just uncomfortable (0 to 4.99), and from just comfortable to very comfortable (5.01 to 10$)$. The test persons were also asked to report if they would prefer more air velocity $(+1)$, less air velocity $(-1)$, or if the velocity from their diffuser was OK $(0)$. in [4].

Further details on the experimental design can be seen

\subsection{Skin temperature and sweat measurements}

Two of the four test persons who participated each day wore a custom-made skin temperature measurement suit. 24 type $\mathrm{T}$ thermocouples were connected to an Intab PClogger 3100i for data acquisition and taped on the test persons skin on 24 locations with medical tape, as shown in Fig. 1 below.

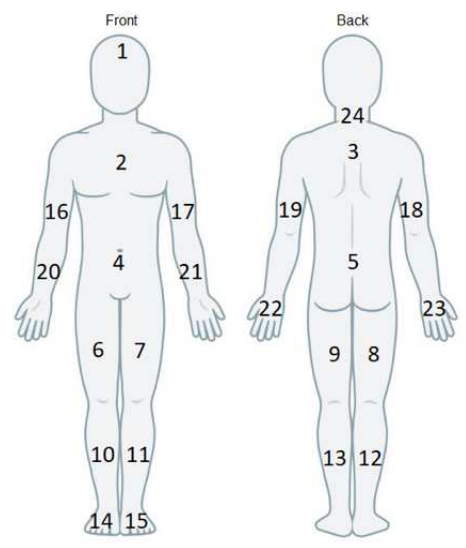

Fig. 1. Skin temperature measurement points
Calculations of mean skin temperature for the whole body and for different body parts were done based on methods described in [5]. The existing 25-point model had to be readjusted to a 24-point skin temperature model due to instrument limitations. The recalculation of the mean skin temperature models was done based on a study for measurements of skin surface area for different parts of the body [6].

All test persons had their palm sweat recorded throughout the day, with a Shimmer3 GSR+ [7] attached around their wrist. Two electrodes were connected to the test persons index and middle finger to measure the conductance in the palms between those two points, as shown in Fig. 2 below.

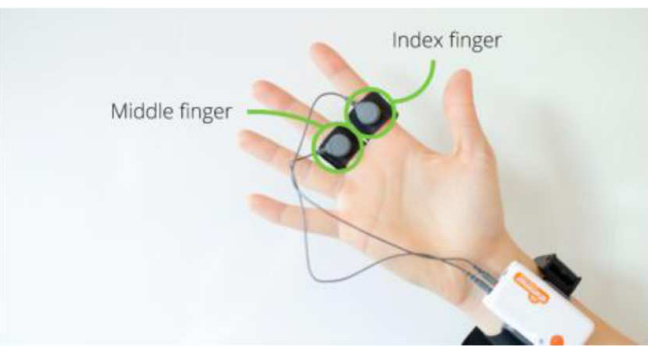

Fig. 2. Palm sweat measurements. Photo: www.imotions.com

Based on the palm sweat measurements, each test person normalized sweat, sweat slope and mean sweat were calculated. Normalized sweat gave each test person a sweat score between 0 and 1 , where all sweat measurements at bottom $0.5^{\text {th }}$ percentile during all three weeks of experiments were given a score of 0 , and all measurements above $99.5^{\text {th }}$ percentile were given a score of 1 . Mean sweat and sweat slope were calculated by using the last five minutes of sweat measurements before the test persons reported their thermal sensation and thermal comfort scores through the electronic questionnaires.

\subsection{Symbolic regression analysis}

The results from the questionnaires and logged skin temperatures were analysed using Eureqa [3], an application for symbolic regression. Eureqa was used to select parsimonious models [8], i.e. models that give the best combination of simplicity and predictive power. This was done by selecting the model with the lowest modified Akaike Information Criterion (AIC) [9], whilst avoiding overfitting [10] by randomly splitting the data half/half into a training set and a validation set. Furthermore, to minimize the influence of outliers, a robust error metric [11] was used, namely the sum of absolute deviations [12] (equivalent to the best-fit function giving the median value).

The following parameters from the questionnaire and skin temperature measurements were used in the regression analysis: 
Table 1. Parameters used for the symbolic regression analysis.

\begin{tabular}{|c|c|c|}
\hline Par. & Description & Unit \\
\hline $\mathrm{c}_{1}$ & $0=$ Male, $1=$ Female & - \\
\hline $\mathrm{c}_{2}$ & $\begin{array}{l}\text { Individual diffuser air speed setpoint } \\
(0.25 / 0.50 / 0.75)\end{array}$ & $\mathrm{m} / \mathrm{s}$ \\
\hline $\mathrm{c}_{3}$ & $\begin{array}{l}\text { Room temperature setpoint } \\
24 / 26 / 28\end{array}$ & ${ }^{\circ} \mathrm{C}$ \\
\hline $\mathrm{s}_{1}$ & $\begin{array}{l}\text { Thermal sensation whole body } \\
(-4 \text { to }+4 ; 0=\text { neutral })\end{array}$ & - \\
\hline s2 & $\begin{array}{l}\text { Thermal sensation head } \\
(-4 \text { to }+4 ; 0=\text { neutral })\end{array}$ & - \\
\hline s3 & $\begin{array}{l}\text { Thermal sensation right arm } \\
(-4 \text { to }+4 ; 0=\text { neutral })\end{array}$ & - \\
\hline $\mathrm{s}_{4}$ & $\begin{array}{l}\text { Thermal sensation left arm } \\
(-4 \text { to }+4 ; 0=\text { neutral })\end{array}$ & - \\
\hline $\mathrm{s} 5$ & $\begin{array}{l}\text { Thermal sensation both hands } \\
(-4 \text { to }+4 ; 0=\text { neutral })\end{array}$ & - \\
\hline $\mathrm{p}_{1}$ & $\begin{array}{l}\text { Thermal comfort whole body } \\
(0 \text { to } 10 ; 0=\text { worst } 10=\text { best })\end{array}$ & - \\
\hline $\mathrm{p}_{2}$ & $\begin{array}{l}\text { Thermal comfort head } \\
\text { ( } 0 \text { to } 10 ; 0=\text { worst } 10=\text { best })\end{array}$ & - \\
\hline $\mathrm{p}_{3}$ & $\begin{array}{l}\text { Thermal comfort right arm } \\
(0 \text { to } 10 ; 0=\text { worst } 10=\text { best })\end{array}$ & - \\
\hline $\mathrm{p}_{4}$ & $\begin{array}{l}\text { Thermal comfort left arm } \\
(0 \text { to } 10 ; 0=\text { worst } 10=\text { best })\end{array}$ & - \\
\hline $\mathrm{p}_{5}$ & $\begin{array}{l}\text { Thermal comfort both hands } \\
(0 \text { to } 10 ; 0=\text { =worst } 10=\text { best })\end{array}$ & - \\
\hline $\mathrm{d}$ & $\begin{array}{l}\text { Would you prefer more air or less air? } \\
\text { (Less }=-1, \mathrm{OK}=0, \text { More }=+1)\end{array}$ & - \\
\hline $\mathrm{t}_{1}$ & $\begin{array}{l}\text { Mean skin temperature } \\
\text { whole body }\end{array}$ & ${ }^{\circ} \mathrm{C}$ \\
\hline $\mathrm{t}_{2}$ & $\begin{array}{l}\text { Mean skin temperature } \\
\text { upper body above abdomen }\end{array}$ & ${ }^{\circ} \mathrm{C}$ \\
\hline $\mathrm{t}_{3}$ & $\begin{array}{l}\text { Mean skin temperature } \\
\text { both arms including hands }\end{array}$ & ${ }^{\circ} \mathrm{C}$ \\
\hline $\mathrm{t}_{4}$ & $\begin{array}{l}\text { Mean skin temperature } \\
\text { both hands }\end{array}$ & ${ }^{\circ} \mathrm{C}$ \\
\hline
\end{tabular}

\section{Results}

\subsection{Thermal sensation}

The boxplots below (Fig. 3-Fig. 7) shows the results from the respondents thermal sensation and measured skin temperatures, for respondents who wore a skin temperature measurement suit.

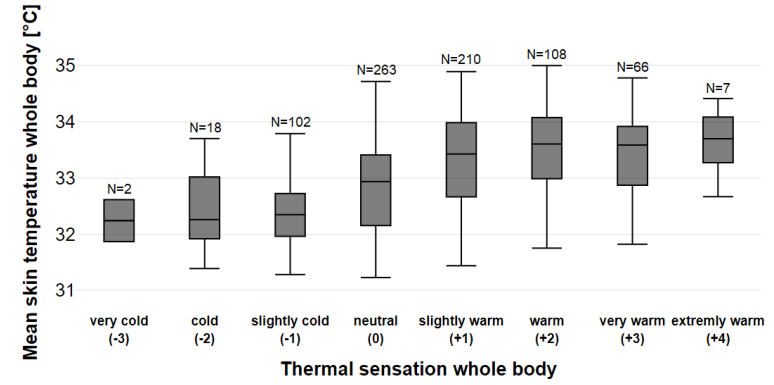

Fig. 3. Boxplot of calculated mean skin temperature whole body for all respondents wearing skin measurement suit, by thermal sensation for whole body $\left(s_{1}\right)$. The dark line inside the box is the median value. The top and bottom of the boxes are the $75^{\text {th }}$ and $25^{\text {th }}$ percentile, while the whiskers shows the minimum and maximum skin temperature values.

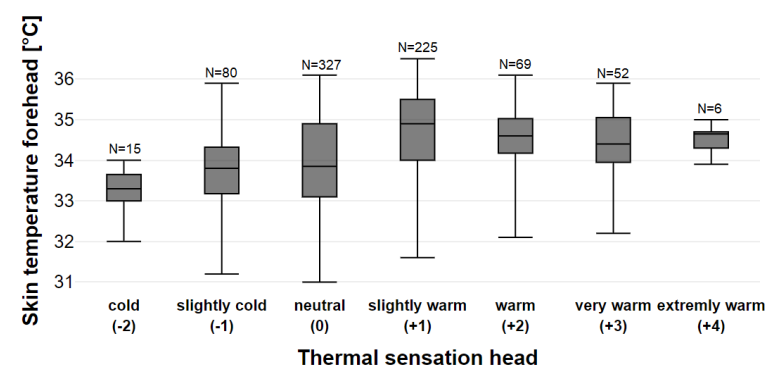

Fig. 4. Boxplot of measured skin temperature forehead for all respondents wearing skin measurement suit, by thermal sensation on the head $\left(s_{2}\right)$. The dark line inside the box is the median value. The top and bottom of the boxes are the $75^{\text {th }}$ and $25^{\text {th }}$ percentile, while the whiskers shows the minimum and maximum skin temperature values.

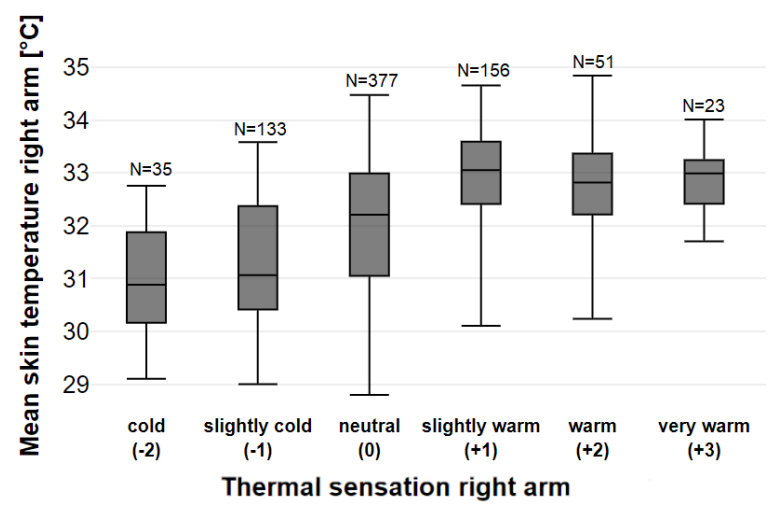

Fig. 5. Boxplot of calculated mean skin temperature right arm for all respondents wearing skin measurement suit, by thermal sensation for right arm $\left(s_{3}\right)$. The dark line inside the box is the median value. The top and bottom of the boxes are the $75^{\text {th }}$ and $25^{\text {th }}$ percentile, while the whiskers shows the minimum and maximum skin temperature values. 


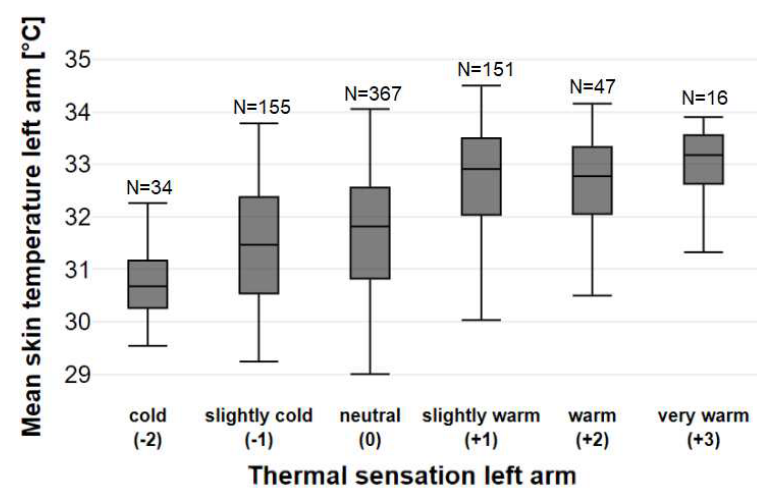

Fig. 6. Boxplot of calculated mean skin temperature right arm for all respondents wearing skin measurement suit, by thermal sensation for left arm $(s 4)$. The dark line inside the box is the median value. The top and bottom of the boxes are the $75^{\text {th }}$ and $25^{\text {th }}$ percentile, while the whiskers shows the minimum and maximum skin temperature values.

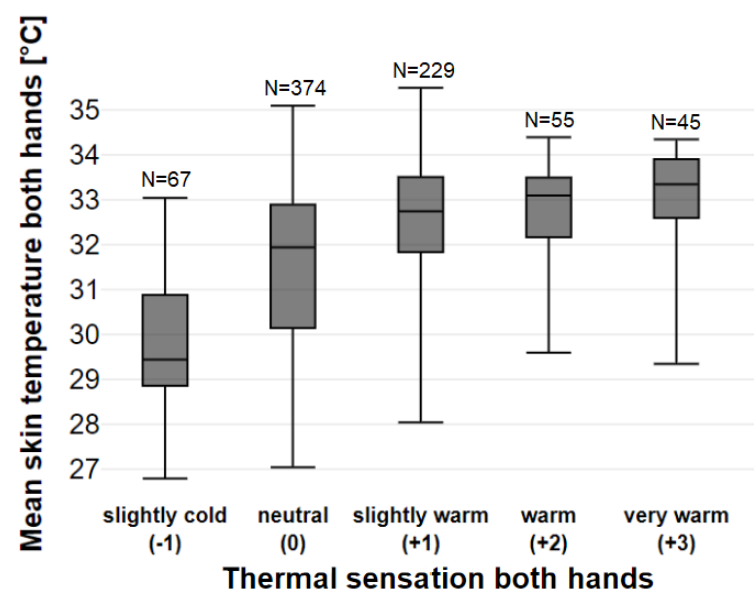

Fig. 7. Boxplot of calculated mean skin temperature both hands for all respondents wearing skin measurement suit, by thermal sensation for both hands $\left(s_{5}\right)$. The dark line inside the box is the median value. The top and bottom of the boxes are the $75^{\text {th }}$ and $25^{\text {th }}$ percentile, while the whiskers shows the minimum and maximum skin temperature values.

Collectively, these results indicate a positive correlation between thermal sensation and measured skin temperatures. These correlations were investigated further in Eureqa, and are presented in Table 2-Table 8 below.

Table 2. Results for thermal sensation scores ( $s_{1}$ to $\left.s_{5}\right)$ for all the questionnaire data, to find the function $f\left(c_{1}, c_{2}, c_{3}\right)$.

\begin{tabular}{|c|c|c|c|}
\hline Equation & $\begin{array}{c}\boldsymbol{R}^{\mathbf{2}} \\
\text { (Goodness } \\
\text { of fit) [13] }\end{array}$ & $\begin{array}{c}\boldsymbol{r} \\
\text { (Correlation } \\
\text { coefficient) [13] }\end{array}$ & Eqn.no. \\
\hline $\mathrm{s} 1$ & 0.3968 & 0.6368 & $(1)$ \\
\hline $\mathrm{s} 2$ & 0.2618 & 0.5322 & $(2)$ \\
\hline $\mathrm{s} 3$ & 0.2807 & 0.5462 & $(3)$ \\
\hline $\mathrm{s} 4$ & 0.2611 & 0.5331 & $(4)$ \\
\hline $\mathrm{s} 5$ & 0.2257 & 0.4757 & $(5)$ \\
\hline
\end{tabular}

$$
\begin{aligned}
& s_{1}=\operatorname{round}\left(0.5014 \cdot c_{2}-12.16-c_{2}\right) \\
& s_{2}=\operatorname{round}\left(0.3468 \cdot c_{2}-8.250-c_{2}\right) \\
& s_{3}=\operatorname{round}\left(0.2314 \cdot c_{2}-5.562-c_{2}\right) \\
& s_{4}=\operatorname{round}\left(0.2275 \cdot c_{2}-5.510-c_{2}\right) \\
& s_{5}=\operatorname{round}\left(0.2482 \cdot c_{2}-5.527-c_{2}\right)
\end{aligned}
$$

Table 3. Removing the round() function from the pool of possible functions, results in the following regressions for thermal sensation scores $\left(s_{1}\right.$ to $\left.s_{5}\right)$ for all the questionnaire data, as a function of $f\left(c_{1}, c_{2}, c_{3}\right)$.

\begin{tabular}{|c|c|c|c|}
\hline Equation & $\begin{array}{c}\boldsymbol{R}^{\mathbf{2}} \\
\text { (Goodness } \\
\text { of fit) [13] }\end{array}$ & $\begin{array}{c}\boldsymbol{r} \\
\text { (Correlation } \\
\text { coefficient) [13] }\end{array}$ & Eqn.no. \\
\hline s1 & 0.3893 & 0.6362 & $(6)$ \\
\hline s2 & 0.3337 & 0.5934 & $(7)$ \\
\hline s3 & 0.3621 & 0.6044 & $(8)$ \\
\hline s4 & 0.3569 & 0.6001 & $(9)$ \\
\hline s5 & 0.2459 & 0.5305 & $(10)$ \\
\hline
\end{tabular}

$$
\begin{aligned}
& s_{1}=0.4999 c_{2}+0.4995 c_{1}-2.002 c_{2}-12.00 \\
& s_{2}=0.3024 c_{1}+0.2502 c_{1}-1.000 c_{2}-7.007 \\
& s_{2}=0.4111 c_{2}+1.000 c_{2}^{2}-1.714 c_{2}-10.15 \\
& s_{4}=0.3612 c_{2}+0.000 c_{1}-1.111 c_{2}-8.837 \\
& s_{5}=0.2507 c_{2}+0.000 c_{1}-1.000 c_{2}-5.767
\end{aligned}
$$

Collectively these results indicate that gender $\left(c_{1}\right)$ as a parameter seems to be overshadowed by other parameters not included in the equation, such as individual differences in metabolism.

The results in Table 2 and Table 3 indicate that an increase in room temperature of $1 \mathrm{~K}$ can be compensated by increasing the supply jet air velocity by 0.25 to $0.5 \mathrm{~m} / \mathrm{s}$ in order to maintain comfortable thermal sensation for the whole body $\left(s_{1}\right)$. For thermal sensation for the head $\left(s_{2}\right)$, a $1 \mathrm{~K}$ increase in room temperature can be compensated by approximately $0.30-0.35 \mathrm{~m} / \mathrm{s}$ increase in jet velocity. For the arms $\left(\mathrm{s}_{3}, \mathrm{~s}_{4}\right)$ and hands $\left(\mathrm{s}_{5}\right)$ it can be compensated by approximately $0.25 \mathrm{~m} / \mathrm{s}$.

The above regression models indicate that it should be possible for users to increase the jet core velocity up to about $1.4 \mathrm{~m} / \mathrm{s}$ in order to be satisfied in $28^{\circ} \mathrm{C}$ environments. To confirm this, the analysis was repeated for the subset of questionnaire data with $28^{\circ} \mathrm{C}$ room temperature:

Table 4. Results for the function $f\left(c_{1}, c_{2}, c_{3}\right)$ for room temperature setpoint of $28^{\circ} \mathrm{C}$ only. Parameters $c_{1}$ and $c_{2}$ are listed in order of significance.

\begin{tabular}{|c|c|c|c|}
\hline Equation & $\begin{array}{c}\boldsymbol{R}^{\mathbf{2}} \\
\text { (Goodness } \\
\text { of fit) [13] }\end{array}$ & $\begin{array}{c}\boldsymbol{r} \\
\text { (Correlation } \\
\text { coefficient) [13] }\end{array}$ & Eqn.no. \\
\hline $\mathrm{s}_{1}$ & -0.1038 & 0.0968 & $(11)$ \\
\hline $\mathrm{s}_{2}$ & 0.0022 & 0.2212 & $(12)$ \\
\hline $\mathrm{s}_{3}$ & -0.1354 & 0.2766 & $(13)$ \\
\hline $\mathrm{s} 4$ & -0.0544 & 0.2208 & $(14)$ \\
\hline $\mathrm{s} 5$ & -0.0502 & 0.0553 & $(15)$ \\
\hline
\end{tabular}




$$
\begin{aligned}
& s_{1}=\operatorname{round}\left(1.602-0.5825 \cdot c_{1}-c_{2}\right) \\
& s_{2}=\operatorname{round}\left(1.619+0.3753 \cdot c_{1}-c_{2}\right) \\
& s_{3}=\operatorname{round}\left(1.889-3.000 \cdot c_{2}\right) \\
& s_{4}=\operatorname{round}\left(0.9032+0.7369 \cdot c_{1}-c_{2}\right) \\
& s_{5}=\operatorname{round}\left(1.000+0.3753 \cdot c_{1}-c_{2}\right)
\end{aligned}
$$

These regressions exhibit the same general tendency as above, i.e. that increased velocity of up to about $1.5 \mathrm{~m} / \mathrm{s}$ can be used to improve skin temperature comfort. However, there are 3 issues:

- The supposed velocity of $1.5 \mathrm{~m} / \mathrm{s}$ has been estimated by extrapolation (to achieve $s=0$ ) and needs to be confirmed by experiment.

- There is an influence of gender $\left(c_{1}\right)$, whereby females appear to be a bit more sensitive to the high environmental temperatures, on the exposed upper part of the body.

- The correlations are very poor, so there are important explanatory variables that have not been accounted for.

One contributory explanation is differences in personal preferences. This can be explored by the following regression:

Table 5. Personal preference for increase in air jet velocity, $d$ $=f\left(c_{1}, c_{2}, c_{3}, s_{1}, s_{2}, s_{3}, s_{4}, s_{5}\right)$.

\begin{tabular}{|c|c|c|c|}
\hline Equation & $\begin{array}{c}\boldsymbol{R}^{\mathbf{2}} \\
\text { (Goodness } \\
\text { of fit) [13] }\end{array}$ & $\begin{array}{c}\boldsymbol{r} \\
\text { (Correlation } \\
\text { coefficient) [13] }\end{array}$ & Eqn.no. \\
\hline$d$ & 0.3049 & 0.6118 & (16) \\
\hline
\end{tabular}

$$
d=\operatorname{round}\left[0.7448+0.2445 s_{1}+0.2445 s_{2}-0.09028 s_{1} s_{2}-c_{2}\right.
$$$$
\left.+c_{1} s_{5}\left(0.1520 s_{4}-0.1420 s_{5}\right)\right]
$$

This regression shows that the individual wish to increase jet air velocity is most strongly related to the thermal sensation whole body $\left(s_{1}\right)$ and thermal sensation head $\left(s_{2}\right)$ and can obviously be offset by changing the jet air velocity $\left(c_{2}\right)$. However, it does not tell us which velocity is required with any confidence.

The above regression equations 1-15 can be applied to estimate the optimum jet air velocity assuming a room temperature of $28^{\circ} \mathrm{C}$, by finding the value of $s_{3}$ that results in optimum thermal sensation $(s=0)$ :

Table 6. Estimated optimum jet air velocity at $28^{\circ} \mathrm{C}$ room temperature $(\mathrm{m}=$ male, $\mathrm{f}=\mathrm{female})$.

\begin{tabular}{|l|c|c|c|c|c|}
\hline \multicolumn{1}{|c|}{$\begin{array}{c}\text { Optimum } \mathbf{s 3}_{\mathbf{1 m}} \\
{[\mathbf{m}]}\end{array}$} & $\begin{array}{c}\text { Eqn. } \\
(\mathbf{1})-\mathbf{( 5 )}\end{array}$ & \multicolumn{2}{c|}{$\begin{array}{c}\text { Eqn. } \\
(\mathbf{6})-(\mathbf{1 0})\end{array}$} & \multicolumn{2}{c|}{$\begin{array}{c}\text { Eqn. } \\
(\mathbf{1 1})-(\mathbf{1 5})\end{array}$} \\
\hline & $\mathbf{m + f}$ & $\mathbf{m}$ & $\mathbf{f}$ & $\mathbf{m}$ & $\mathbf{f}$ \\
\hline Whole body $\left(\mathrm{s}_{1}\right)$ & 1.88 & 1.00 & 1.25 & 1.60 & 1.02 \\
\hline Forehead $\left(\mathrm{s}_{2}\right)$ & 1.46 & 1.46 & 1.71 & 1.62 & 1.99 \\
\hline Right arm $\left(\mathrm{s}_{3}\right)$ & 0.92 & - & - & 0.63 & 0.63 \\
\hline Left arm $\left(\mathrm{s}_{4}\right)$ & 0.86 & 1.15 & 1.15 & 0.90 & 1.64 \\
\hline Hands $\left(\mathrm{s}_{5}\right)$ & 1.42 & 1.25 & 1.25 & 1.00 & 1.38 \\
\hline
\end{tabular}

From Table 6 above, one can conclude that is should be possible to increase the jet core velocity to about 1.5 $\mathrm{m} / \mathrm{s}$ in $28^{\circ} \mathrm{C}$ environments, and that some occupants may choose to point the jet at their head or chest instead of their exposed arms, or might even adapt by wearing longsleeved shirts.

If the SvalVent solution is to be implemented in environments that are cooled to a maximum operative

\begin{tabular}{|c|c|c|c|}
\hline \multirow[t]{2}{*}{ Optimum $s_{3}[\mathrm{~m} / \mathrm{s}]$} & \multirow{2}{*}{$\frac{\text { Eqn. (1)-(5) }}{m+\mathbf{f}}$} & \multicolumn{2}{|c|}{$\begin{array}{c}\text { Eqn. } \\
\text { (6)-(10) }\end{array}$} \\
\hline & & $\mathbf{m}$ & f \\
\hline Whole body $\left(\mathrm{s}_{1}\right)$ & 0.88 & 0.50 & 0.75 \\
\hline Forehead $\left(\mathrm{s}_{2}\right)$ & 0.77 & 0.86 & 1.11 \\
\hline Right $\operatorname{arm}\left(\mathrm{s}_{3}\right)$ & 0.45 & - & - \\
\hline Left arm (s4) & 0.41 & 0.50 & 0.50 \\
\hline Hands (s5) & 0.93 & 0.75 & 0.75 \\
\hline
\end{tabular}
temperature of $26^{\circ} \mathrm{C}$ in the summer, then regression equations 1-10 indicate that the maximum jet air velocity $\left(s_{3}\right)$ should be as follows:

Table 7. Estimated optimum jet air velocity at $26^{\circ} \mathrm{C}$ room temperature $(\mathrm{m}=$ male, $\mathrm{f}=$ female $)$.

From the above table, one can conclude that a maximum jet velocity of $0.75 \mathrm{~m} / \mathrm{s}$ is about enough for $26^{\circ} \mathrm{C}$ environments, but that this may cause local discomfort on some occupants' arms if they are bare.

\subsection{Measured skin temperature}

Table 8. Results for measured skin temperatures $\left(t_{1}\right.$ to $\left.t_{4}\right)$ as a function of $f\left(c_{1}, c_{2}, c_{3}\right.$. Parameters $\left(c_{3}, c_{1}, c_{2}\right)$ are listed in order of significance:

\begin{tabular}{|l|c|c|c|}
\hline Equation & $\begin{array}{c}\boldsymbol{R}^{\mathbf{2}} \\
\text { (Goodness } \\
\text { of fit) [13] }\end{array}$ & $\begin{array}{c}\boldsymbol{r} \\
\text { (Correlation } \\
\text { coefficient) [13] }\end{array}$ & Eqn.no. \\
\hline$t_{1}$ & 0.6401 & 0.8018 & $(176)$ \\
\hline$t_{2}$ & 0.5089 & 0.7241 & $(18)$ \\
\hline$t_{3}$ & 0.7272 & 0.8535 & $(19)$ \\
\hline$t_{4}$ & 0.5807 & 0.7640 & $(20)$ \\
\hline
\end{tabular}

$$
\begin{gathered}
t_{1}=21.78+0.4486 \cdot c_{3}-0.2102 \cdot c_{1}-0.4946 \cdot c_{2}(12) \\
t_{2}=21.33+0.4751 \cdot c_{3}-0.2949 \cdot c_{1}-0.6575 \cdot c_{2}(13) \\
t_{3}=15.55+0.6491 \cdot c_{3}-0.3199 \cdot c_{1}-0.7194 \cdot c_{2}(14) \\
t_{4}=10.24+0.8524 \cdot c_{3}-1.0000 \cdot c_{2}
\end{gathered}
$$

These regression models indicate that females appear to have on average approximately 0.2 to $0.3 \mathrm{~K}$ lower mean skin temperature than males. This confirms earlier studies of skin temperature, and observations that females are more sensitive to cold environments [14].

This analysis shows that comfortable thermal sensation can be achieved in warm environments by increasing the local air velocity, and that this effect is more noticeable on the upper parts of the body that are exposed to the supply air jet. A $1 \mathrm{~K}$ increase in environmental temperature can be offset by a $0.8-0.9 \mathrm{~m} / \mathrm{s}$ increase in jet core velocity.

Further analyses are required before publishing results on the test persons palm sweat measurements. 


\subsection{Air jet preferences}

These results confirm the questionnaire responses about jet air velocity preferences, as tabulated below. Each cell in Table 9-Table 11 below contains the number of respondents:

Table 9. Results for $24^{\circ} \mathrm{C}$ room temperature, for thermal sensation whole body and preferred jet velocity. A chi-square test of independence was performed to examine the relation between thermal sensation whole body and preferred jet speed. The relation between these was significant, $X^{2}(4, N=516)=$ $162.0, p<.00001$.

\begin{tabular}{|l|c|c|c|}
\hline & $\begin{array}{c}\text { Skin feels } \\
\text { cold }\end{array}$ & $\begin{array}{c}\text { Skin feels } \\
\text { OK }\end{array}$ & $\begin{array}{c}\text { Skin feels } \\
\text { hot }\end{array}$ \\
\hline Want less air & $\mathbf{1 3 3}$ & 24 & 15 \\
\hline Jet speed OK & 96 & $\mathbf{1 5 7}$ & 27 \\
\hline Want more air & 10 & 24 & $\mathbf{3 0}$ \\
\hline
\end{tabular}

Table 10. Results for $26^{\circ} \mathrm{C}$ room temperature, for thermal sensation whole body and preferred jet velocity. A chi-square test of independence was performed to examine the relation

between thermal sensation whole body and preferred jet velocity. The relation between these was significant, $X^{2}(4, N=$ $551)=185.4, p<.00001$

\begin{tabular}{|l|c|c|c|}
\hline & $\begin{array}{c}\text { Skin feels } \\
\text { cold }\end{array}$ & $\begin{array}{c}\text { Skin feels } \\
\text { OK }\end{array}$ & $\begin{array}{c}\text { Skin feels } \\
\text { hot }\end{array}$ \\
\hline Want less air & $\mathbf{2 7}$ & 21 & 16 \\
\hline Jet speed OK & 27 & $\mathbf{1 8 3}$ & 63 \\
\hline Want more air & 9 & 50 & $\mathbf{1 5 3}$ \\
\hline
\end{tabular}

Table 11. Results for $28^{\circ} \mathrm{C}$ room temperature, for thermal sensation whole body and preferred jet speed. A chi-square test

of independence was performed to examine the relation

between thermal sensation whole body and preferred jet velocity. The relation between these was significant, $X^{2}(4, N=$ $552)=118.8, p<.00001$

\begin{tabular}{|l|c|c|c|}
\hline & $\begin{array}{c}\text { Skin feels } \\
\text { cold }\end{array}$ & $\begin{array}{c}\text { Skin feels } \\
\text { OK }\end{array}$ & $\begin{array}{c}\text { Skin feels } \\
\text { hot }\end{array}$ \\
\hline Want less air & $\mathbf{1}$ & 3 & 9 \\
\hline Jet speed OK & 1 & $\mathbf{8 2}$ & 74 \\
\hline Want more air & 0 & 43 & $\mathbf{3 3 9}$ \\
\hline
\end{tabular}

Preferably the responses should lie in the darkcoloured cells, which indicates that there is a positive correlation between thermal sensation and jet air velocity preference. Respondents in the light-coloured cells indicate contradictory preferences, that skin thermal sensation cannot be improved by adjusting jet velocity alone. Fortunately, there are relatively few respondents in the light-coloured cells.

These results confirm what we already know, that Fanger's PMV.PPD model for overall thermal comfort says that we can compensate for higher room setpoint temperature by increasing air velocity around the human body, as illustrated in EN 15251:2007 Figure A.2, and confirm that individuals wish to increase the jet core velocity significantly above $0.75 \mathrm{~m} / \mathrm{s}$ when the room temperature is $26^{\circ} \mathrm{C}$ or higher.
Additional results on acceptable air velocities can be seen in [4].

\section{Discussion}

The results from this climate chamber experiment indicate that the that a jet air velocity from the SvalVent diffusers around the body of $0.75 \mathrm{~m} / \mathrm{s}$ is about enough to give most of our test persons satisfactory thermal comfort at a room temperature of $26^{\circ} \mathrm{C}$ (Table 7). However, at a room temperature of $28^{\circ} \mathrm{C}$ a $0.75 \mathrm{~m} / \mathrm{s}$ jet air velocity will be insufficient for many occupants. Our estimates suggest that a jet air velocity around the body of about $1.5 \mathrm{~m} / \mathrm{s}$ for $28^{\circ} \mathrm{C}$ room temperatures should be sufficient (Table 6), but this needs to be confirmed by further research and experiments.

Our measurements on skin temperature indicate a 0.2 $-0.3 \mathrm{~K}$ lower mean skin temperatures on the whole body and different body parts for females (Table 8). This confirms what we know from earlier studies [14-15] and might be an explanatory factor to why females in general appear more thermal sensitive to colder room temperatures than males.

During this controlled climate chamber experiment the test persons themselves did not control the jet air velocity during the sessions, and the highest air velocity for the prototype used was $0.75 \mathrm{~m} / \mathrm{s}$ around the body of the test persons. Table $\mathbf{9}$ to Table $\mathbf{1 1}$ gives us an indication that there is a positive correlation between thermal sensation and the test persons desire the change jet air velocity. This was particularly noticeable at $28^{\circ} \mathrm{C}$ room temperature.

As a proof of concept, the SvalVent solution should be tested with fully individually controlled diffusers with possibilities for higher jet air velocities than the limit of $0.75 \mathrm{~m} / \mathrm{s}$ for the prototype used in this climate chamber experiment.

\section{Conclusion}

The SvalVent concept can give satisfactory thermal comfort at room temperatures up to $26^{\circ} \mathrm{C}$, but will require higher air jet velocities than the limit of the SvalVent prototype of $0.75 \mathrm{~m} / \mathrm{s}$ used in this climate chamber experiment for room temperatures above $28^{\circ} \mathrm{C}$ to ensure satisfactory thermal comfort.

This paper is based on the master theses by Håkon R. Solberg and Henrik S. Nordby, as a part of the SvalVent project. SvalVent is funded by the Research Council of Norway EnergiX program together with the industry partners GK Inneklima, Trox Auranor Norge, Topro Industrier and Entra. Research partner is Oslo Metropolitan University.

\section{References}

1. NVE, "Analyse av energibruk i yrkesbygg," Oslo (2016)

2. K. Thunshelle, "Oppvarming via tilluft," SINTEF akademisk forlag, Oslo (2016). 
3. Wikipedia, "Eureqa application from Nutonian," [Online]. Accessed: 2020. Available: https://en.wikipedia.org/wiki/Eureqa.

4. K. Thunshelle, H. Nordby, H. Solberg, S. Holøs and P. Schild, "Acceptable air velocities using demand controlled ventilation for individual cooling," in NSB 2020, Tallinn (2020).

5. T. Sakoi, K. Tsuzuki, S. Kato, R. Ooka, D. Song and S. Zhu, "Thermal comfort, skin temperature distribution, ...," in Building and Environment, vol. 42, AIST, pp. 3984-3999 (2007)

6. Y. Kurazumi, T. Horikoshi, T. Tsuchikawa and N. Matsubara, "The body surface area of Japanese," Japanese Journal of Biometeorology, vol. 31, pp. 5-29 (1994)

7. Shimmer, "Shimmer3 wireless GSR sensor," [Online]. Accessed: 2020. Available: https://www.shimmersensing.com/products/shimm er3-wireless-gsr-sensor

8. Wikipedia, "Law of parsimony," [Online]. Accessed: 2020. Available: https://en.wikipedia.org/wiki/Occam\%27s_razor

9. Wikipedia, "Akaike information criterion," [Online]. Accessed: 2020. Available: https://en.wikipedia.org/wiki/Akaike_information_ criterion

10. Wikipedia, "Overfitting," [Online]. Accessed: 2020. Available: https://en.wikipedia.org/wiki/Overfitting

11. Wikipedia, "Robust regression," [Online]. Accessed: 2020. Available: https://en.wikipedia.org/wiki/Robust_regression

12. Wikipedia, "Least sum of absolute deviations," [Online]. Accessed: 2020. Available: https://en.wikipedia.org/wiki/Least_absolute_devi ations

13. Nutonian, "Eureqa error metrics documentation," [Online]. Accessed: 2020. Available: http://formulize.nutonian.com/documentation/eure qa/general-reference/error-metrics/

14. T. Chang and A. Kajackaite, "Battle for the thermostat: Gender and the effect of temperature on cognitive performance.," (2019)

15. H. Kim, C. Richardson, J. Roberts, L. Gren and J. Lyon, "Cold hands, warm heart.," no. 351, p. 1492, (1998) 